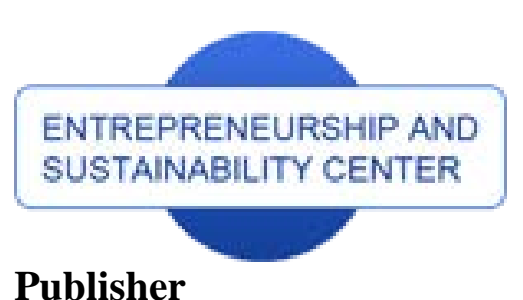

Publisher

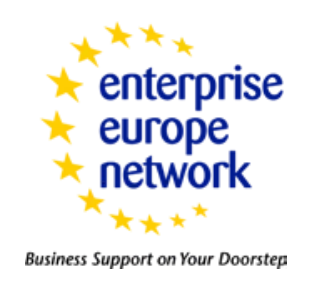

\title{
CLUSTER PERFORMANCE: AN ATTEMPT TO EVALUATE THE LITHUANIAN CASE*
}

\author{
Salvatore Monni ${ }^{1}$, \\ Francesco Palumbo ${ }^{2}$, Manuela Tvaronavičiené ${ }^{3}$ \\ 1.2 Università degli Studi Roma Tre, Via Silvio D’Amico 77, Rome IT-00145, Italy \\ ${ }^{3}$ Vilnius Gediminas Technical University, Sauletekio 11, Vilnius LT-10223, Lithuania \\ E-mails: ${ }^{\text {salvatore.monn@uniroma3.it; } 2 \text { fra.palumbo3@stud.uniroma3.it } \underline{3} \text { maunela.tvaronaviciene@vgtu.lt }}$
}

Received 13 April 2017; accepted 10 June 2017

\begin{abstract}
The article takes place in the research area of the ongoing European project 'Cluster Development Med' (Horizon 2020) regarding the innovation and technology in the sustainable development field. Authors suggest a model, which allows to identify the most successful clusters and make comparisons between and within them. The analysis defines where they perform a positive or negative trend in the area examined. The model embraces three dimensions of cluster activity, so called, "Resources, Activities, Processes". They have been determined on the work of the Lithuanian association "Knowledge Economy Forum", called "Cluster Analysis". Data for practical evaluation purposes were obtained through two stage process. First, an interview on site with the coordinators of the Lithuanian clusters for data collection was done through a questionnaire survey, developed in collaboration with the Science and Innovation Agency of the Lithuanian Government. Secondly, the data have been aggregated by applying one of multi-criteria methods, specifically, Simple Additive Weighting method. Finally, the multi-criteria analysis results were used to estimate the efficiency of the clusters. The results were compared through suggested benchmarking. Suggested model can be used for evaluation of performance of different clusters.
\end{abstract}

Keywords: cluster; firm performance; cluster performance; performance measurement; Lithuania

\footnotetext{
${ }^{*}$ This research was supported by the project, which has received funding from the European Union's Horizon 2020 research and innovation programme European Research Council (ERC) under the European Union's Horizon 2020 research and innovation programme Marie Sklodowska-Curie Research and Innovation Staff Exchanges ES H2020-MSCA-RISE-2014 CLUSDEVMED (2015-2019) Grant Agreement Number 645730730
}
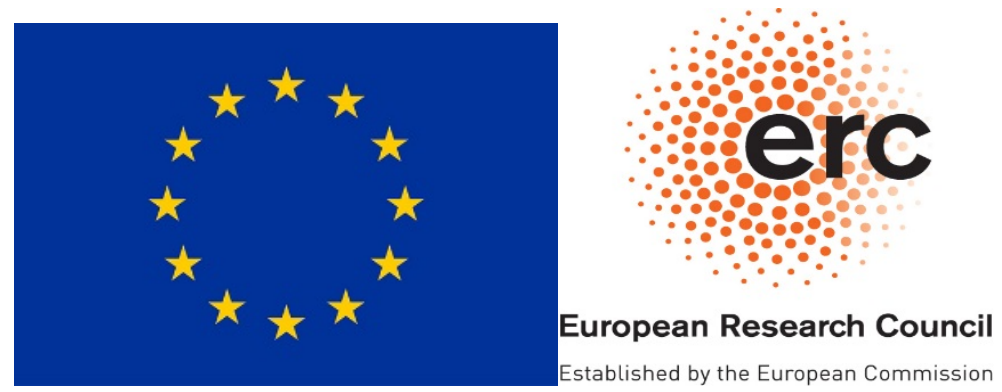
The International Journal
ENTREPRENEURSHIP AND SUSTAINABILITY ISSUES

ISSN 2345-0282 (online) http://jssidoi.org/jesi/

2017 Volume 5 Number 1 (September)

http://doi.org/10.9770/jesi.2017.5.1(4)

Reference to this paper should be made as follows: Monni, S.; Palumbo, Tvaronavičienè, M. 2017. Cluster performance: an attempt to evaluate the Lithuanian case, Entrepreneurship and Sustainability Issues 5(1): 43-57. http://doi.org/10.9770/jesi.2017.5.1(4)

JEL Classifications: L25; R10

\section{Introduction}

According to Nuur (2005) clusters have long been part of the industrial framework, with geographic agglomerations of business and enterprises in specific industries existing since centuries. Agglomeration economies had been first developed by Marshall (1920) and further by Arrow (1962), Romer (1986) and many other scholars (OECD, 2007). Over the last decades, cluster policy has been widely analyzed by Porter (1990, 1998), who claims that clusters are composed by firms and industries linked through vertical (buyer/supplier) and/or horizontal (common customers, technology, etc.) relationships with the main players located in a single nation/state. This definition was further analyzed by several scholars (Rosenthal and Strange, 2004; Delgado, Porter, and Stern, 2014; Ellison and Glaeser, 1997; Kerr and Kominers, 2015; Krugman, 1991).

Several governments and industry organizations all over the world have made use of this concept in recent years as a mean to encourage urban and rural economic growth. As a result, a high level of cluster initiative organizations started during the 1990s, and the trend continues (Bevilacqua, 2011). An analysis of cluster initiatives around the globe, covered more than 1400 cluster initiative organizations, was carried out in the "Cluster Initiative Greenbook" published by Orjan Solvell, Christian Ketels and Goran Lindqvist, with a foreword by Michael Porter (Andersson, 2004). The attempt of the work is to use benchmarking to measure the cluster performance of the clusters. Benchmarking is a good practice in business among organizations to improve performance and competitiveness, but it is rarely used to check cluster parameters in Lithuania (Tvaronaviciene, 2015). Some scholars as Rodriguez-Pose (2017) claim about cluster performance that firms in small regions may suffer because of shortages of skills and limited externalities. These limitations can be partially overcome by potentially higher levels of social capital and interpersonal trust (Maskell and Malmberg, 1999), although greater collaboration and embeddedness may both facilitate the generation and transformation of skills and knowledge into industrial performance (Fitjar and Rodríguez-Pose, 2017) or, conversely, lead to lock-in and stifle the capacity of local firms to remain competitive and productive (Boschma, 2005; Rodríguez-Pose and Crescenzi, 2008).

\section{Approaches towards cluster perception}

Clusters and their literature to study them are various and multidimensional. They require a wide variety of tools to be deeply understood and appreciated. Even though there are several studies carried out in different countries, there is not a common compromise of the cluster concept has not been generally accepted yet. "Clusters are geographic concentrations of interconnected companies and institutions in a particular field. Clusters encompass an array of linked industries and other entities important to competition. They include, for example, suppliers of specialized inputs such as components, machinery, and services, and providers of specialized infrastructure” (Porter, 1998, pp.11). One of the main characteristics of clusters is to support the economic growth of enterprises in specific working sectors or create new businesses in larger industries of a geographic area. Industrial clusters perform as instruments in strengthening the innovative capabilities of firms, industries and even nations. "The phenomenon of cluster appears as an evolution of the traditional industrial districts. It reveals factors in common such as cultural approach, knowledge transfer, social capital and institutions” (Monni and Spaventa, 2007, pp.175). According to Porter, "clusters also often extend downstream to channels and customers and laterally to manufacturers of complementary products and to companies in industries related by skills, technologies, or 
The International Journal

ENTREPRENEURSHIP AND SUSTAINABILITY ISSUES

ISSN 2345-0282 (online) http://jssidoi.org/jesi/

2017 Volume 5 Number 1 (September)

http://doi.org/10.9770/jesi.2017.5.1(4)

common inputs" (Porter, 1998, pp.78). Moreover, most of the clusters embrace governmental and other institution supporting for specialized training, education, technical aid, research and information. Clusters involve a disposition of interconnected industries and other entities important to competition (Porter, 1998). However, talking about clusters does not concern only geographic and physical relation, but it specially focus on the social and human relation between a wide array of members such as institutions, universities, research centers and enterprises, where the synergy gets even more importance between public and private sector (Monni and Spaventa 2007, 2009; Zemlickiene et al. 2017; Fuschi, Tvatonavičienè 2016; Ahmed et al. 2017; Razminienè et al. 2016).

We aim at claiming that clusters develop and therefore strengthen their competitiveness, through the "combination of inter-firm rivalry and collaboration (so called "co-opetition"), innovation and the rapid transmission and adoption of ideas, and the generation of important local externalities, such as a skilled labour pool, the availability of specialized inputs" (FAO, 2010, pp.3). Cluster are in continuous evolution, facing the challenge of the stakeholders and the only solution is the cooperation between companies within and between clusters. Reduced input costs of the manufacturers, development of common suppliers, training of professional labor and a technical knowledge spillover effect can be achieved through the formation of clustering (Hsu, 2014; Morrison et al., 2013; Prause, Atari 2017; Hilkevics, Hilkevics, 2017).

\section{The strategic role of Small and Medium Enterprises}

According to Karaev (2007), clusters are identifiable as an essential mean for improving SMEs productivity, innovativeness and overall competitiveness through overcoming their size limitations (Kljucnikov and Popesko, 2017). The knowledge of clusters represents an opportunity for small and medium enterprises to improve their market position. The purpose is to encourage the cooperation as well the competition between them, in such a way to accelerate the processes of innovation. "Numerous examples, in both industrialized and developing countries, demonstrate that SME cluster have established themselves as important and dynamic players within the international market responding to global competition challenges by capitalizing on local opportunities and collective competitive advantage” (UNIDO Programme, 2001, pp. 10).

Cluster competitiveness aims at enhancing SMEs' size, performance, innovation and employment; therefore it is used to assessing their outcomes in terms of capital invested and equity returns. The findings from a difference-indifferences analysis reveal that sales, employment, R\&D investments, and value added all increase in relative terms, but financial returns exhibit significant relative decreases for the smallest companies, whereas larger firms record strong increases (Broekel et al., 2015; Kozubikova et al., 2017). The ineptitude of the least modest SMEs to take advantage from their cluster membership should be more discussed for both companies and policy-makers (Braune et al., 2016).

"It is characteristic to clusters to sustain productivity growth of firms in specific regions or create new businesses in larger sectors of a particular nation. Industrial clusters perform as instruments in strengthening the innovative capabilities of firms, industries and even nations. The main feature of the cluster, which exposes itself in the long run is that companies within cluster increase their competence of an organization and achieve a competitive advantage in global markets” (Tvaronavičienè et al., 2015b pp.120). Therefore, identifying the dominant problem groups facing the company can enable an estimate of the level of knowledge available in the enterprise. Classifying micro, small and medium enterprises (M-SME) based on their available levels of knowledge, specific problems that dominate a company's operations are considered. "About half of the M-SME shows a lower level of available knowledge, and only $10 \%$ are categorized with the highest level. There should be not wide differences between the size and the level of available knowledge of the company. Thus, employment and sales' level of MSMEs is not followed as a logical consequence by an accumulation of knowledge which firms can benefit to improve their operations” (Lopez-Ortega et al., 2016, pp 1). SMEs have an essential role in the cluster framework. 
By funds they get, they can invest in R\&D, enhance knowledge, increase innovation and improve quality of life (Rodríguez-Pose and Crescenzi, 2008). Here it is also aimed at examining "how technology transfer is being approached in the latest scientific literature, and whether interrelations of technology transfer and sustainable development are being elaborated. Clusters in this context are perceived as networks (not necessarily proximate in geographic terms), which serve as technology transmitters” (Tvaronaviciene, 2015b, pp. 87).

\section{ClusDevMed: a Horizon 2020 project for cluster}

The 'Cluster Development Med' (ClusdevMED) is a project funded by the European Union, MarieSkłodowskaCurie Actions under the Research and Innovation Staff Exchange scheme (RISE) -Horizon 2020 Programme.

CusdevMed Project's areas of interest are those that concern the implementation of research and innovation about the sustainable development field: e-learning, educational technology, green technology, affordable and healthy food, energy efficiency and renewable energy, water reuse and wastewater treatment. It aims at improving the sustainable development through the secure access to food and energy worldwide, relying on win-win share of sectoral use of constrained natural resources, such as land and water, taking also in account the crucial role of ecosystems and their services (Karabulut, 2017).

The project lies within priority research and innovation topics in EU cooperation, as highlighted in several past projects and policies recommendations, i.e. within the MOCO - Monitoring Committee for European Cooperation in RTD. International Cluster Cooperation offers opportunities to scale up research and technological potential, enhance competitiveness, support the regional socio-economic development and reinforce the market placement of new, innovative products. These cooperation approaches often fail due to constraints on resources, capabilities, instruments and funding. On the other hand, over two-thousands clusters only in the European Union covering all sectors and able to realize an inter-sectoral framework, as well as related clusters and networks in the southern Mediterranean countries, form a great potential for transnational clustering (European Commission, 2014) ${ }^{\dagger}$.

\section{Metodology}

Below we provide object, approach to data collection and methods used, what is embraced by methodology of research.

Object. Concerning the research and innovation about the sustainable development field for the ClusDevMed project, it is interesting to focus on the Baltic regions' experience and to analyse in depth the Lithuanian case. Recently there are less than fifty clusters initiatives in Lithuania. Some of them are still at the initial formation, or is a group of companies that gathered together seeking only for EU SF aid. From all the identified clusters in Lithuania only a forth is formed naturally, by common work aiming at bigger part of market and increasing competitiveness of cluster companies, in a long-term co-operation perspective to develop of new products or services (Tvaronaviciene, 2015b). Seven successful clusters have been selected according to the following criteria: "they have been operating for longer than two years, receive funding either from EU funds or private institutions and the results of cluster activity are satisfactory” (Tvaronaviciene, 2015a, 122). Because of the strong partnership and trade connections, of the similar characteristics showed and, specially, because of the same working business area, that is food and agriculture, it was decided to include even the cluster from Latvia (Food Products Quality Cluster), also for the reason why it produces a wide contribution to the analysis. The research concerns different fields of cluster: the aim is to compare clusters through every kind of field and then focus on cluster of the Lithuanian agricultural sector. The following clusters are the one being interviewed: the Latvian

\footnotetext{
† For further information about 'ClusDevMed' Project, please refer to the European Commission webpage, http://cordis.europa.eu/project/rcn/196630_en.html
} 


\section{The International Journal}

ENTREPRENEURSHIP AND SUSTAINABILITY ISSUES

ISSN 2345-0282 (online) http://jssidoi.org/jesi/ 2017 Volume 5 Number 1 (September) http://doi.org/10.9770/jesi.2017.5.1(4)

'Food Products Quality Cluster' (Cluster A), of which the main target is to promote cooperation between Latvian food enterprises and increase their export potential; the 'Smart Food Cluster' (Cluster B) aims at helping companies from Lithuanian Food Exporters Association to increase competitiveness in foreign markets by uniting the capabilities, expertise and contacts; the 'Uzupis Creative Cluster' (Cluster C), that wants to establish and build a strong, international simulation game development community, to develop educational simulation games cluster, which in the design of products and competence would be able to compete in international markets, create and implement innovative new technologies and solutions in the field of educational simulation games, combining and developing the potential of Lithuania; the 'iVita Wellness Cluster' (Cluster D) purpose is to develop high quality and added value wellness products and services which increase people's safety, their performance efficiency, contribute to prevention, education of society and development of healthy lifestyle habits; the 'Vilnius Film Cluster' (Cluster E) not only provides top-quality services, but also actively cooperates with Lithuanian and foreign partners, supports young creators, organizes professional development events and mastery courses for film industry specialists; the 'Baltic Automotive Components Cluster' (Cluster F), aims at uniting the Lithuanian (Baltic) companies involved in the manufacturing of automotive and farm equipment; the 'Laser and Engineering Technology Cluster' (Cluster G), of which the first goal is to create a dynamic activity center with a fully integrated supply chain of suppliers, manufacturers, and sellers, which would enhance the international competitive ability of the sector of laser and related technologies as well as knowledge and material well-being of its individual members ${ }^{\ddagger}$.

Clusters' performance in Lithuania: approach to data collection. Studies related to performance of clusters are widely discussed in scientific literature: scholars debate such aspects as measuring of innovations (Rezk at al. 2015), approaches and methods (Maffioli, Pietrobelli, Stucchi, 2016) of cluster analysis, technology transfer processes and driving forces; composition and governance specifics; participation of start-ups. Hence, spectrum of questions related to clustering phenomena is wide (Razminiene, 2016). At the initial stage an interview with the coordinators of the seven clusters selected in Lithuania was arranged (Appendix, part A). The main aim of the meeting was to get information from a person who has been participating in the life of cluster from the beginning of it about the successful clusters in Lithuania. "As it is complicated to measure how successful cluster is some features were named as obligatory which characterize cluster and show how good it is ac accomplishing goals, if the companies are working together for a common purpose. Measurements such as cluster activity, resources and processes must be taken into account” (Tvaronaviciene, 2015a). Successively, the managers were asked to give evaluations for indicators of cluster efficiency according to their importance so that a multi-criteria analysis could be carried out. A multi-criteria analysis was chosen for it serves in making a comparative assessment among heterogeneous measures. At the last stage the data was structured and a multi-criteria analysis carried out to prove the efficiency of the clusters. The results were compared through benchmarking.

Multicriteria SAW method. Multi-criteria methods are used for both theoretical and practical tasks since they are universal and enable to carry out a quantitative study for any complex phenomenon with many indices (Ginevičius, 2008). The multicriteria SAW (Simple Additive Weighting) method was applied to process the results. The adopted model embraces three dimensions of cluster activity, so called, "Resources, Activities, Processes" (Ziniu Ekonomikos Forumas, 2012). The work suggests an approach for cluster performance assessment, based on the multi-evaluation, which covers a wide range of indicators. We assume, that cluster effectiveness should be evaluated according to the suggested indicators showed in the Appendix (part B). Let us explain the steps through which it was possible to get these values. First, as mentioned above, a questionnaire survey was delivered to clusters' managers that decided to participate at the analysis. The questionnaire has been developed in collaboration with the 'Science, Innovation and Technology Agency' (MITA) of the Lithuanian

\footnotetext{
‡ For further information about the clusters analysed, please refer to the European Cluster Collaboration Platform webpage, https://www.clustercollaboration.eu/cluster-list
} 
The International Journal

ENTREPRENEURSHIP AND SUSTAINABILITY ISSUES

ISSN 2345-0282 (online) http://jssidoi.org/jesi/ 2017 Volume 5 Number 1 (September) http://doi.org/10.9770/jesi.2017.5.1(4)

Government. It is composed by two principal parts: in the first one, the managers were asked to give some data (for each indicator of Resources and Processes dimension) and an evaluation from 1 to 10 (for each indicator of Activities); while in the second one they were asked to attribute a number of Importance to these indicators, still from 1 to 10 (Ziniu Ekonomikos Forumas, 2012). The next step was to sum the seven different evaluations up (since the interviewed managers were seven) of each indicator of the first part (Table 1). For logistic reasons, it is only showed the 'Resources' dimension, but it is possible to consult the whole questionnaire in the appendix B.

Table 1. Data and respective Sum

\begin{tabular}{|c|c|c|c|c|c|c|c|c|}
\hline & cluster A & cluster B & cluster $C$ & cluster D & cluster $E$ & cluster F & cluster $G$ & Sum \\
\hline units & 1 & 1 & 1 & 3 & 2 & 1 & 10 & 19 \\
\hline units & 52 & 18 & 13 & 11 & 22 & 17 & 13 & 146 \\
\hline units & 0 & 2 & 18 & 0 & 3 & 0 & 8 & 31 \\
\hline units & 0 & 20 & 9 & 0 & 0 & 0 & 0 & 29 \\
\hline units & 25 & 14 & 20 & 20 & 1 & 9 & 2 & 91 \\
\hline units & 25 & 7 & 12 & 2 & 0 & 0 & 2 & 48 \\
\hline Eur & 212000 & 200000 & 1000000 & 96319 & 1000000 & 0 & 1448100 & 3956419 \\
\hline Eur & 38000 & 400000 & 1000000 & 192637.9 & 1000000 & 60000 & 2896200 & 5586838 \\
\hline
\end{tabular}

Later on, we passed to the normalization: it was obtained dividing each number of the evaluations by the value of the indicator that refers to the evaluation. These values are included between 0 and 1 (Table 2).

Table 2. Normalization

\begin{tabular}{|c|c|c|c|c|c|c|c|}
\hline & cluster A & cluster B & cluster C & cluster D & cluster E & cluster F & cluster G \\
\hline units & 0.052632 & 0.052632 & 0.052632 & 0.157895 & 0.105263 & 0.052632 & 0.526316 \\
\hline units & 0.356164 & 0.123288 & 0.089041 & 0.075342 & 0.150685 & 0.116438 & 0.089041 \\
\hline units & 0 & 0.064516 & 0.580645 & 0 & 0.096774 & 0 & 0.258065 \\
\hline units & 0 & 0.689655 & 0.310345 & 0 & 0 & 0 & 0 \\
\hline units & 0.274725 & 0.153846 & 0.21978 & 0.21978 & 0.010989 & 0.098901 & 0.021978 \\
\hline units & 0.520833 & 0.145833 & 0.25 & 0.041667 & 0 & 0 & 0.041667 \\
\hline Eur & 0.053584 & 0.050551 & 0.252754 & 0.024345 & 0.252754 & 0 & 0.366013 \\
\hline Eur & 0.006802 & 0.071597 & 0.178992 & 0.034481 & 0.178992 & 0.01074 & 0.518397 \\
\hline
\end{tabular}

Source: Authors' elaboration

Then, the same process was carried out for the second part: first, the levels of satisfaction (from one to ten) attributed by the managers (still seven, because of the seven different managers) of the same indicators were summed. Therefore, to get the final weight, each of these numbers (numbers of importance) was divided by the respective sum that refers to the indicator (Table 3). 
The International Journal

ENTREPRENEURSHIP AND SUSTAINABILITY ISSUES

ISSN 2345-0282 (online) http://jssidoi.org/jesi/ 2017 Volume 5 Number 1 (September) http://doi.org/10.9770/jesi.2017.5.1(4)

Table 3. Level of satisfaction and respective weight

\begin{tabular}{|l|l|l|l|l|l|l|l|l|}
\hline cluster A & cluster B & cluster $C$ & cluster D & cluster E & cluster F & cluster G & Sum & Weight \\
\hline 7 & 8 & 8 & 8 & 7 & 7 & 7 & 52 & 0.138298 \\
\hline 5 & 7 & 6 & 8 & 6 & 8 & 8 & 48 & 0.12766 \\
\hline 5 & 7 & 6 & 6 & 6 & 7 & 6 & 43 & 0.114362 \\
\hline 6 & 6 & 7 & 6 & 5 & 7 & 6 & 43 & 0.114362 \\
\hline 8 & 6 & 6 & 7 & 6 & 7 & 7 & 47 & 0.125 \\
\hline 7 & 6 & 7 & 7 & 6 & 7 & 7 & 47 & 0.125 \\
\hline 6 & 6 & 7 & 7 & 7 & 5 & 7 & 45 & 0.119681 \\
\hline 7 & 7 & 8 & 8 & 7 & 7 & 7 & 51 & 0.135638 \\
\hline & & & & & & & 376 & 1 \\
\hline
\end{tabular}

Source: Authors' elaboration

Finally, the last step was to multiply this weight by the respective final value (always seven final values for each indicator) obtained in the first part (Table 4). The values that refer to each cluster, obtained by this last multiplication, were summed up to get seven final results of each category (Table 5).

Table 4. Results of each indicator

\begin{tabular}{|l|l|l|l|l|l|l|}
\hline cluster A & cluster B & cluster C & cluster D & cluster E & cluster F & cluster G \\
\hline 0.007221 & 0.007221 & 0.007221 & 0.021664 & 0.014442 & 0.007221 & 0.072212 \\
\hline 0.047927 & 0.01659 & 0.011982 & 0.010138 & 0.020277 & 0.015668 & 0.011982 \\
\hline 0 & 0.00732 & 0.065878 & 0 & 0.01098 & 0 & 0.029279 \\
\hline 0 & 0.078246 & 0.035211 & 0 & 0 & 0 & 0 \\
\hline 0.034069 & 0.019079 & 0.027255 & 0.027255 & 0.001363 & 0.012265 & 0.002726 \\
\hline 0.064589 & 0.018085 & 0.031003 & 0.005167 & 0 & 0 & 0.005167 \\
\hline 0.006362 & 0.006002 & 0.03001 & 0.002891 & 0.03001 & 0 & 0.043458 \\
\hline 0.000915 & 0.009634 & 0.024086 & 0.00464 & 0.024086 & 0.001445 & 0.069758 \\
\hline
\end{tabular}

Source: Authors' elaboration

Table 5. Final results given by the sum of each indicator of each dimension

\begin{tabular}{|l|l|l|l|l|l|l|l|}
\hline & $\mathrm{A}$ & $\mathrm{B}$ & $\mathrm{C}$ & $\mathrm{D}$ & $\mathrm{E}$ & $\mathrm{F}$ & $\mathrm{G}$ \\
\hline Resources & 0.161083 & 0.162177 & 0.232646 & 0.071755 & 0.101158 & 0.0366 & 0.234582 \\
\hline Activities & 0.115136 & 0.17156 & 0.185494 & 0.172831 & 0.107213 & 0.13342 & 0.114345 \\
\hline Processes & 0.110547 & 0.123034 & 0.169496 & 0.154892 & 0.252739 & 0.056116 & 0.133176 \\
\hline Total & 0.386767 & 0.45677 & 0.587636 & 0.399478 & 0.461111 & 0.226136 & 0.482103 \\
\hline
\end{tabular}

Benchmarking was chosen as the most reasonable method of data analysis to serve the purpose of this article. As a process benchmarking, this method serves to compare the three main dimensions which reveal cluster efficiency: activity, resources and processes (Carpinetti, 2008). Based on this methodology, there must be a continuous monitoring performance of clusters. These indicators must be assessed at least once every two years, to verify the collection of relevant data clusters and interview survey methods. In order to increase cluster performance, it should be based on cluster performance assessment results, establishing appropriate incentive measures to ensure the changes in values and simultaneously ensuring the efficiency of the whole cluster. 


\section{The International Journal \\ ENTREPRENEURSHIP AND SUSTAINABILITY ISSUES}

ISSN 2345-0282 (online) http://jssidoi.org/jesi/

2017 Volume 5 Number 1 (September)

http://doi.org/10.9770/jesi.2017.5.1(4)

\section{Between and within analysis: empirical results}

Looking at 'Final results' table (Table 5), it is possible to compare clusters between them. Concerning the 'Resources' dimension, Cluster C and G perform high values specially for the reason why they have been receiving lots of financings and making wide investments. As it concerns 'Activities' dimension, Cluster $\mathrm{C}$ stands out again because it shows a clear satisfaction in the organization and logistic of the cluster. Then, with reference to the 'Processes' dimension, Cluster E demonstrates the highest value because it especially invests in training for developing the personnel. The aim of the research is to focus on Cluster B, Smart Food Cluster. We aim at analyzing Smart Food Cluster because it takes place in the agribusiness and agricultural sector and it is the most relevant to the ClusdevMed topic that is Sustainable Development.nIt is positioned in the middle cluster group with the $\mathrm{E}$ and $\mathrm{G}$ ones. By taking a look at each value of $\mathrm{B}$, it is still in the middle level for 'Resources' and 'Processes', while it gets a relative higher value for Activities, taking part to the top of performance cluster ranking. What does it need to do to improve its performance? For instance, to develop the resources, it has to increase the skilled personnel (having a highest education) and raise the financing level, while to improve the activities it needs to focus on the visual identification (i.e. logo, brand, image) and specially on the cooperation and technology transfer; then to show a better performance in processes, there must be an increase of the expenses in Research and Development and of the level of internalization of the cluster, that means a launch to import and export business.

Cluster resources include all assets, capabilities, organizational processes, firm attributes, information, knowledge, etc. controlled by a firm that enable the firm to conceive of and implement strategies that improve its efficiency and effectiveness. Thus, in the language of traditional strategic analysis firm resources are strengths that firms can use to conceive of and implement their strategies. Here resources regard human resources and know-how, financial resources, infrastructure resources (Barney, 1991). Cluster activities regard the value chain that a firm operating in a specific industry performs in order to deliver a valuable product or service for the market. The idea of the value chain is based on the process view of organizations, the idea of seeing a manufacturing (or service) organization as a system, made up of subsystems each with inputs, transformation processes and outputs. Inputs, transformation processes, and outputs involve the acquisition and consumption of resources - money, labour, materials, equipment, buildings, land, administration and management. How value chain activities are carried out determines costs and affects profits human resources development, Cluster competitive situation changes, cluster innovation changes, Cluster internationality level (Jurevicius, 2013). Cluster processes are a collection of related, structured activities or tasks that produce a specific service or product (serve a particular goal) for a particular customer or customers. It may often be visualized as a flowchart of a sequence of activities with interleaving decision points or as a process matrix of a sequence of activities with relevance rules based on data in the process. They include Market activity, Marketing and public relations communications, internal communication, External communication (Competitiveness and Innovation Framework Programme, 2011). The clusters were selected paying attention to their performance regardless of the industry sector as for generic benchmarking. "As to agree with the principles for benchmarking (Carpinetti 2008), some restrictions were applied to this article". In order to verify legal aspects of the study, statistical data are given in the normalized. All the benchmarking partners will receive the same type of information for perceiving mutual benefits. Benchmarking data will be communicated outside for study purpose as it was prior agreed with benchmarking partners. To sum up, after comprising all the steps that have been taken moving towards the results of this study, generic benchmarking process has been followed. At first cluster efficiency was determined as a subject of this benchmarking study. Then a coordinator of cluster development in Lithuania as a consultant for choosing the partners was approached. Later seven clusters were identified as the partners of the study four of which participated in the process of benchmarking. Further step was to collect and analyze data using 
questionnaire survey and multi-criteria analysis methods to serve the purpose. Finally, the results were implemented and monitored.

\section{Conclusions}

This article aims at comparing the most successful clusters, in the given conditions, in Lithuania. After comprising all the steps that have been taken moving towards the results of this study, generic process has been followed. Cooperation and competition are factors that encourage the growth of clusters, both within and between them. Thus, Smart Food Cluster, that regards 'Agriculture products' and 'Processed Food', mainly arises in the Activities category where it has one of the highest values while in the Resources category shows medium-high values. By analyzing the cluster framework, we can say most of the clusters could perform better learning from some areas such as the Agriculture and Food one. They can adopt the same strategies or start a collaboration with it. For instance, they can improve in Resources on hiring more graduated people or increasing investments for cluster initiatives. While for Activities, they can show a better performance focusing on the image of the cluster in mass media or, even, sharing more knowledge and experience. On the other hand, Smart Food Cluster and the respective Agriculture and Food sector needs to improve in the Processes category: their values are between the medium-lowest of the analysis, for instance they can increase the R\&D expense or the number of official agreements with foreign entities.

\section{References}

Ahmed, A.; McGough, D.; Mateo-Garcia, M. 2017. Testing innovative technologies for retrofitting: Coventry University as a living lab, Entrepreneurship and Sustainability Issues 4(3): 257-270. https://doi.org/10.9770/jesi.2017.4.3S(2)

Andersson, T. 2004. The Cluster Policies Whitebook. International Organisation for Knowledge Economy and Enterprise Development http://citeseerx.ist.psu.edu/viewdoc/download?doi=10.1.1.197.4531\&rep=rep1\&type=pdf

Arrighetti, A.; Seravalli, G. 1999. Istituzioni Intermedie E Sviluppo Locale. Roma: Published by Donzelli.

Arrow, K. 1962. Economic Welfare and the Allocation of Resources for Invention, in R. Nelson (ed.). The Rate and Direction of Inventive Activity. Princeton, NJ: Princeton University Press, 609-626.

Barney, J. 1991. Firm Resources and Sustained Competitive Advantage. Journal of Management 17(1): 99-120. http://www.bms.lk/download/PGD/slides/Strategic-Planning-Materials/Barney-1991-strategy.pdf

Bevilacqua, C. 2011. A new paradigm to conciliate neo-liberal economy and sustainable urban regeneration https://www.unido.org/fileadmin/user_media/Services/PSD/Clusters_and_Networks/publications/sme_brochure_EN.pdf

Boschma, R.A. 2005. Proximity and innovation: a critical assessment. Regional Studies 39, 61-74. http://dx.doi.org/10.1080/0034340052000320887

Bosworth, B.; Broun, D. 1996. Connect the Dots: Using Cluster-Based Strategies to Create Urban Employment. Firm Connections 4(2): 16.

Braune et al. 2016. The Performance of Independent Active SMEs in French Competitiveness Clusters. Industry and Innovation 4(23): 313-330. http://dx.doi.org/10.1080/13662716.2016.1145574

Broekel, Tom, Fornahl, Dirk, Morrison, Andrea, 2015. Another cluster premium: Innovation subsidies and R\&D collaboration networks. Research Policy, Elsevier 44(8): 1431-1444. https://doi.org10.1016/j.respol.2015.05.002

Carpinetti, L.C.R.; Oiko, O.T. 2008. Development and application of a benchmarking information system in clusters of SMEs, Benchmarking: An International Journal 15 (3): 292 - 306. https://doi.org/10.1108/14635770810876601 
Cerezo, Y. et al. 2015. The UVF adapted Quintuple Helix Model “CICLIA” a New Globalized Educational Proposal.

Commercial Local Urban Districts. SIU (The Society of Italian Urban Planners) - XIV Conference. Selected papers, Ed. By Costa, E.; Bevilacqua, C.; Trillo, C.; Trupiano, G. March, 24-25-26, Turin, Italy. file://C:/Users/Manuela/Downloads/costa_etal.pdf

Competitiveness and Innovation Framework Programme. 2011. Cassandra: a multivariate platform for assessing the impact of strategic decisions in electrical power systems.

Delgado, M.; Porter, M; Stern, S. 2014. Clusters, Convergence, and Economic Performance. Research Policy 43(10): 1785-1799. https://doi.org/10.3386/w18250

Ellison, G.; Glaeser, E.L.; Kerr, W. R. 2010. American Economic Review (100): 1195-1213. http://www.aeaweb.org/articles.php?doi=10.1257/aer.100.3.1195

Ellison, G.; Glaeser, E. 1997. Geographic Concentration in U.S. Manufacturing Industries: A Dartboard Approach. The Journal of Political Economy 105(5): 889-927. http://citeseerx.ist.psu.edu/viewdoc/download?doi=10.1.1.548.1673\&rep=rep1\&type=pdf

European Commission, 2014. European Commission: CORDIS: Projects 6 Results Service: Cluster Development Med http://cordis.europa.eu/project/rcn/196630_it.html

FAO, 2010. Agricultural Management, Marketing and Finance Occasional Paper: Agro-based clusters in developing countries: staying competitive in a globalized economy. Research Paper No. 25/10. http://www.fao.org/docrep/012/i1560e/i1560e.pdf>

Fitjar, R.D., Rodríguez-Pose, A., 2017. Nothing is in the air. Growth Change 48: 22-39. https://doi.org/10.1111/grow.12161

Fuschi, D. L.; Tvaronavičienė, M. 2016. A network based business partnership model for SMEs management, Entrepreneurship and Sustainability Issues 3(3): 282-289. https://doi.org 10.9770/jesi.2016.3.3(5)

Ginevičius, R., Podvezko, V. 2008. Daugiakriterinio vertinimo taikymo galimybès kiekybiniam socialinių reiškinių vertinimui, Verslas: Teorija ir praktika (Possibilities of multi-criteria methods for evaluation of social phenomena quantitate evaluation, Business: Theory and Practice) 9 (2): 81 - 87. https://doi.org/10.3846/1648-0627.2008.9.81-87

Hilkevics, S.; Hilkevics, A. 2017. The comparative analysis of technology transfer models, Entrepreneurship and Sustainability Issues 4(4): 540-558. https://doi.org/10.9770/jesi.2017.4.4(11)

Hsu, M.; Lai, Y; Lin, F. 2014. The impact of industrial clusters on human resource and firms performance, Journal of Modelling in Management 9(2): 141-159. https://doi.org/10.1108/JM2-11-2012-0038

Jurevicius, O. 2013. Value Chain Analysis. Strategic Management Insights. Available on the internet https://www.strategicmanagementinsight.com/tools/value-chain-analysis.html

Karaev A.; Lenny Koh, S.C.; Szamosi, L.S. 2007. The cluster approach and SME competitiveness: a review, Journal of Manufacturing Technology Management 18(7): 818-835. www.emeraldinsight.com/doi/abs/10.1108/17410380710817273

Kerr, W. R.; Kominers, S.D. 2015. Agglomerative Forces and Cluster Shapes, The Review of Economics and Statistics 97(4): 877-899. https://doi.org/10.1162/REST a 00471

Kljucnikov, A., Popesko, B. (2017). Export and its Financing in The SME Segment. Case Study From Slovakia. Journal of Competitiveness 9(1): 20-35. https://doi.org/10.7441/joc.2017.01.02

Kozubikova, L., Homolka, L., Kristalas, D. (2017). The Effect of Business Environment and Entrepreneurs': Gender on perception of financial risk in the SMEs sector. Journal of Competitiveness 9(10): 36 - 50. https://doi.org/10.7441/joc.2017.01.03

Krugman, P. 1991. Geography and Trade. Cambridge, MA: Published by MIT Press.

Lin, J.Y.; Nugent, J.B. 1996. Institutions and Economic Development, in Chenery H. - Srinivasan T.N. - Behrman J. (eds.), Handbook of Development Economics, North Holland: 2301-2370. https://doi.org/10.1016/j.respol.2015.05.002 
Lopez-Ortega, E. et al. 2016. Classification of micro, small and medium enterprises (M-SME) based on their available levels of knowledge. Technovation 47: 59-69. https://doi.org/10.1016/j.technovation.2015.10.001

Maffioli, A.; Pietrobelli, C; Stucchi, R. 2016. The impact Evaluation of Cluster Development Programs: Method and Practices. New York: Published by Inter-American Development Bank. file://C:/Users/Manuela/Downloads/The-Impact-Evaluation-of-Cluster-DevelopmentPrograms-Methods-and-Practice.pdf

Marshall A. 2000. Principles of Economics. London: Published by Macmillan.

Maskell, P.; Malmberg, A. 1999. Localised learning and industrial competitiveness. Camb. J. Econ. 23: 167-185. https://doi.org https://doi.org/10.1093/cje/23.2.167

Monni, S.; Spaventa, A. 2007. What Next? How the Internationalisation Process Might Lead to the Dissolution of Veneto's LowTechnology Industrial Districts. Rivista di Politica Economica: 171-217. http://hdl.handle.net/11590/148372

Monni, S.; Spaventa, A. 2009. Cluster e distretti tecnologici: modelli e politiche, in Argomenti 26: 71-98. https://doi.org/10.3280/ARG2009-026004

Morrison, A.; Rabellotti, R; Zirulia, L. 2013. When Do Global Pipelines Enhance the Diffusion of Knowledge in Clusters?, Economic Geography 89(1): 77-96.

Nuur, C. 2005. Cluster dynamics and industrial policy in peripheral regions: a study of cluster formation as a local development process. Stockholm: Pubilshed by Universitetsservice US AB. https://www.divaportal.org/smash/get/diva2:13761/FULLTEXT01.pdf

OECD (Organisation of Economic Co-Operation and Development). 2007. Competitive Regional Clusters. National Policy Approaches. Paris: Published by OECD. http://www.oecd.org/cfe/regional-policy/competitiveregionalclustersnationalpolicyapproaches.htm

Pietrobelli, C.; Rabellotti, R. 2007. Upgrading to Compete: Clusters and Value Chains in Latin America. Cambridge, MA: Published by Harvard University Press.

Porter, M. 2000. Location, Competition, and Economic Development: Local Clusters in a Global Economy, Economic Development Quarterly 14(1): 15-34. https://doi.org/10.1177/089124240001400105

Porter, M. 1998. Clusters and the New Economics of Competition, Harvard Business Review, 76(6): 77-90 https://hbr.org/1998/11/clustersand-the-new-economics-of-competition

Prause, G.; Atari, S. 2017. On sustainable production networks for Industry 4.0, Entrepreneurship and Sustainability Issues 4(4): 421431. https://doi.org/10.9770/jesi.2017.4.4(2)

Putnam R. 1993. Making Democracy Work: Civic Traditions In Modern Italy. Princeton: Published by Princeton University Press. https://books.google.lt/books?hl=lt\&lr=\&id=gKZP8_Tp27UC\&oi=fnd\&pg=PP1\&dq=Putnam+R.+1993.+Making+Democracy+Work:+Civ ic+Traditions+In+Modern+Italy.+Princeton:+Published+by+Princeton+University+Press\&ots=5p4BpIeE_O\&sig=F1Cx1z2SnzA_eav7E_u W2asqW0g\&redir_esc=y\#v=onepage\&q=Putnam\%20R.\%201993.\%20Making\%20Democracy\%20Work\%3A\%20Civic\%20Traditions\%2 0In\%20Modern\%20Italy.\%20Princeton\%3A\%20Published\%20by\%20Princeton\%20University\%20Press\&f=false

Razminienè, Kristina; Tvaronavičienė, Manuela; Zemlickienė, Vaida. 2016. Evaluation of cluster efficiency tool, Terra Economicus 14(3): 101-111. DOI: http://dx.doi.org/10.18522/2073-6606-2016-14-3-101-111

Rezk, M.R.A.; Ibrahim, H.H.; Tvaronavičienė, M.; Sakr, M.M; Piccinetti, L. (2015). Measuring of innovation activities in Egypt: the case of industry, Entrepreneurship and sustainability issues 3(1): 47-55. http://dx.doi.org/10.9770/jesi.2016.3.4(1)

Rodríguez-Pose, A., Crescenzi, R., 2008. Research and development, spillovers, innovation systems, and the genesis of regional growth in Europe. Regional Studies 42: 51-67. https://doi.org 10.1080/00343400701654186

Romer, P. 1986. Increasing Returns and Long Run Growth, Journal of Political Economy 94: 1002-1037.

Rosenthal, S., and W. Strange. 2004. Evidence on the Nature and Sources of Agglomeration Economies, Handbook of Regional and Urban Economics 4: 2119-2171. http://www.econ.brown.edu/Faculty/henderson/WillAndStuart.pdf 
Tvaronavičienė M.; Razminienė, K.; Piccinetti, L. 2015a. Cluster efficiency study through benchmarking, Entrepreneurship and Sustainability Issues 3(2):120-128. http://dx.doi.org/10.9770/jesi.2015.3.2(0)

Tvaronavičienè, M.; Černevičiūtè, J. 2015b. Technology transfer phenomenon and its impact on sustainable development, Journal of Security and Sustainability Issues 5(1): 87-97. DOI: http://dx.doi.org/10.9770/jssi.2015.5.1(7)

UNIDO Programme, 2001. Development of Clusters and Networks of SMEs. Available on the Internet

Zemlickiene, V.; Mačiulis, A.; Tvaronavičienè, M. 2017. Factors impacting the commercial potential of technologies: expert approach, Technological and Economic Development of Economy 23(2): 410-427 http://dx.doi.org/10.3846/20294913.2016.1271061

Ziniu Ekonomikos Forumas, 2012. Klaster Studija, Vilnius. Available on the internet http://www.mita.lt/uploads/documents/teisine informacija/zef klasteriu studija.pdf

\section{Appendix}

Part A. Interview to Smart Food Cluster Manager: Mr. Giedrius Bagusinskas, Vilnius, 21 September 2016

Clusters have been an added value for both economic growth and society itself. "Cluster members are linked by common economic interests, by selling the products and (or) services of the value chain activities" - emphasizes Kestutis Šetkus, Lithuanian Innovation Centre (LIC) Director, of which the main goal is to provide the innovation support services by implementing Lithuanian innovation policy and is the increasing of Lithuanian international competitiveness by stimulating innovations in business. Productivity, competitive advantage both in local and international markets, innovative products, improving the competence of personnel and partners and corporate customers may be some of a number of results that may be achieved by acting together cluster members.

According to Giedrius Bagušinskas, Smart Food Cluster coordinator and Lithuanian Food Exporters Association Manager, the cluster is the development of a form that enables innovation and exports and makes it a powerful force with a strong breakthrough in business. "Our Exclusivity was primarily in the fact that we have started cooperating because of the need to increase competitive advantage and improve business performance in foreign markets". First of all, it was born in informal exporters club, was followed by Lithuanian food exporters association establishment. Then three years later he founded Smartfood Cluster. An important aspect of this cluster development - the first in Lithuania, where the organization has enabled companies not only to compete.

"Like every business, sometimes you get one or other market conjuncture factors and internal communication problems between the cluster members, but all this is only a temporary difficulty, which helps to overcome and make strong corporate agreements on common and measurable economic objectives” notes G. Bagušinskas.

Businesses find common cross-sectoral cooperation between cluster members and actively initiate implementation of joint initiatives that focus on new products and / or services development and export increase (international cooperation) that helps the Science, Innovation and Technology Agency (MITA), Lithuanian Innovation Centre (LIC) and "Enterprise Lithuania (VL), the project initiative " Business and science Partnership internationality promotion "- all of which give measurable results, notes LIC Director K. Šetkus. It is important not only to communicate the coming problems, but also to consult with the Lithuanian Innovation Centre observes the cluster Smartfood coordinator.

"In a relatively short period of time, our company participated in 14 international exhibitions and 8 target food sector business missions to establish contacts with suppliers and retail networks, initiated and successfully developed three innovative co-production projects. All this enabled the emergence of 20 new and returning customers in foreign markets. Giedrius Bagušinskas notes: "We are the first in our sector organization during Lithuania's independence history, have a clear and focused long-term strategy, and launched several of our regular export companies".

Value added of "Smartfood" is to operate together helps to connect minds and optimize performance, then to go out in international waters, to achieve global competitiveness. 


\section{Part B. Set of indicators}

\section{Resources}

Number of cluster coordinating members

Number of cluster members - companies, R\&D subjects, supporting organizations

Number of R\&D personnel

University graduates working at cluster companies

Common cluster projects in two years

Financed common cluster projects in two years with cluster initiatives co-financing

External financing for cluster initiatives in two years

Total sum of cluster members' investments for cluster initiatives in two years

\section{Activities}

Common supply and order scheme

Common distribution channels

Common cluster members' proposals for external clients

Exchange of common market information between cluster members

Cluster advertisement (leaflets, media)

Common participation in exhibitions and trade show

Lobbying

Common internet site

Visual identification (common logo, brand)

Contacts and image of cluster in mass media

Regular meetings of cluster members

Cluster integration events

Common communication platform

Common cluster publications (booklets, newsletters, etc.)

Co-operation while creating new products or technologies

Co-operation while creating innovations (organizational, marketing, etc.)

Common training, workshops, conferences, internships

Common data base

Informal sharing of knowledge and experience

Transference of technologies

\section{Processes}

Increase of cluster members' employees in two years

Number of internal cluster training participants in two years

Number of cluster organized common training in two years

Number of qualification upgraded employees in two years

Increase of direct employment in cluster innovative activities

Part of R\&D expenses in common expenses in two years

Number of common submitted/funded EU SF projects in two years 
Number of common international R\&D projects, funded not from EU SF, in two years

Products/goods of cluster, sold in internal market

Products/goods of cluster, sold in external market

New cluster members in two years

Start-up in cluster

Foreign markets where members of cluster work

Part of export in total cluster sales

Number of official co-operation agreements with foreign entities

Participation in international exhibitions and sales offices in two years

\section{Acknowledgements}

This research was supported by the project, which has received funding from the European Union's Horizon 2020 research and innovation programme European Research Council (ERC) under the European Union's Horizon 2020 research and innovation programme Marie Sklodowska-Curie Research and Innovation Staff Exchanges ES H2020-MSCA-RISE-2014 CLUSDEVMED (2015-2019) Grant Agreement Number 645730730

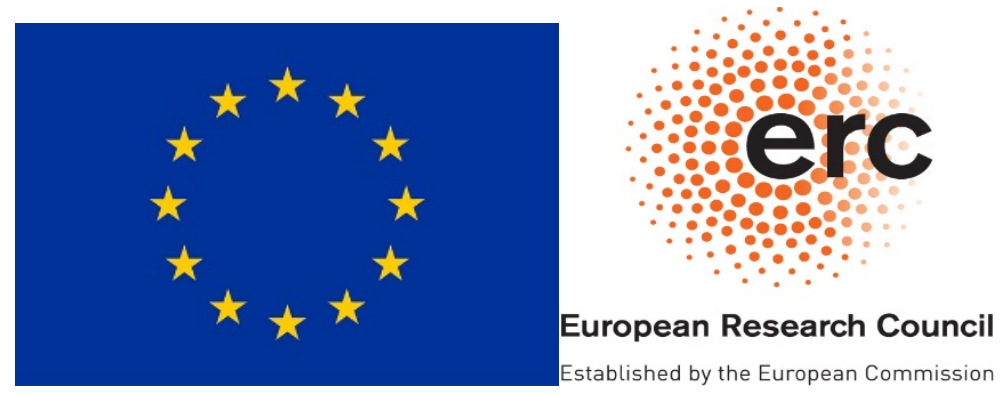


Salvatore MONNI is Associate Professor of Economic Policy and Director of the Master Program in "The Cooperative Firm: Economics, Law and Management", at Roma Tre University, Department of Economics. His current main research and publications are in the fields of development economics and policy. Salvatore is a graduate from "La Sapienza" (Rome, Italy), holds a Master of Arts in Development Economics from the University of Sussex (Brighton, UK) and a Ph.D. in Economics from Roma Tre University (Italy). He is Coordinator of SHUMED (Sustainable Human Development for MED Countries) and AguaSociAL (Social Innovation in Brazil, in the Water Treatment Sector), two FP7 Marie Curie Action People Projects and CLUSDEV MED (Cluster Development Med), an H2020 MSCA RISE project.

ORCID ID: orcid.org/0000-0002-6326-5714

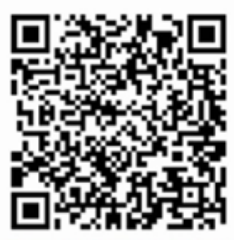

Francesco PALUMBO is a researcher, currently enrolled in a master's degree in Economics and Management of the Co-operative sector and held a post-graduate degree in Environmental and Development Economics. During his studies, he spent several months in Vilnius (Lithuania) for research thesis, working for 'ClusDevMed' Horizon 2020 project. His current main research is in Cluster Development and Cluster Performance. His interests concern Sustainable Development as well Agribusiness and Food Security.

ORCID ID: orcid.org/0000-0003-0011-4211

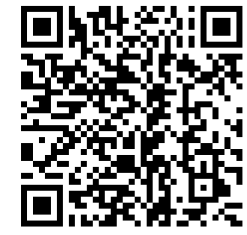

Manuela TVARONAVIČIENE் is professor at Vilnius Gediminas Technical University of Lithunia. She is national head of European Union's Horizon 2020 research and innovation programme European Research Council (ERC) under the European Union's Horizon 2020 research and innovation programme Marie Sklodowska-Curie Research and Innovation Staff Exchanges ES H2020-MSCA-RISE-2014 CLUSDEVMED (2015-2019) Grant Agreement Number 645730730

ORCID ID: orcid.org/0000-0002-9667-3730

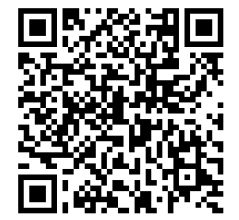

Copyright (C) 2017 by author(s) and VsI Entrepreneurship and Sustainability Center This work is licensed under the Creative Commons Attribution International License (CC BY). http://creativecommons.org/licenses/by/4.0/

cC) (i) Open Access 